\title{
PENDIDIKAN ISLAM DENGAN \\ NILAI-NILAI DAN BUDAYA \\ (Pewarisan Nilai-nilai dan Budaya)
}

\section{Ishak Talibo}

\begin{abstract}
ABSTRAK
Pendidikan merupakan faktor penting dan menentukan dalam kehidupan suatu bangsa dan berbudaya.Kemajuan suatu bangsa sangat tergantung pada tingakat pendidikan yang di perolehnya.Sistem pendidikan Nasional dilaksanakan untuk meningkatkan kehidupan yang bermutu baik dalam arti moral spiritual maupun mutu dalam arti intelektual professional.Pendidikan Islam merupakan bagian integral dalam sistem pendidikan Nasional memiliki konstribusi yang besar dalam penanam nilai-nilai dan budaya serta perilaku keberagaman pada setiap diri seseorang.Penanaman nilai-nilai dan budaya pada seseorang atau sekelompok orang melalui pendidikan Islam akan terbentuklah sikap dan perilaku rujukan dan keyakinan dalam menentukan suatu pilihan bagi seseorang, yang tercermin dalam pola pikir, tingka laku, dan serta sikap. Seperti kejujuran, keadilan, kebenaran dijadikan sebagai pegangan dalam hidupnya.
\end{abstract}

Kata Kunci: Pendidikan Islam, Nilai, Budaya

\section{A. PENDAhULUAN}

Pendidikan merupakan suatu perkara klasik yang sudah ada sejak adanya manusia di dunia ini, sehingga dikatakan bahwa pendidikan adalah hidup ${ }^{1}$ itu sendiri.Artinya pendidikan merupakan bagian integral (tak terpisahkan) dari kehidupan manusia. Dimana ada manusia di situ ada proses pendidikan. Ia berlangsung sepanjang hidup manusia dalam segala lingkungan dan situasi hidup. Hal ini disebabkan karena pendidikan itu dimaksudkan untuk melanjutkan kehidupan dan mencapai tujuan dalam menjalani kehidupan.

Tujuan pendidikan seperti itu merupakan yang asli didapati dalam kehidupan manusia.Dalam bangsa yang sudah modern seperti dewasa ini, pendidikan sudah merupakan pekerjaan yang terorganisasi dengan rapih. Segalah aspek yang terdapat didalamnya diatur secara baku dan

\footnotetext{
${ }^{1}$ Radja Mudyaharjo, Pengantar Pendidikan: Sebuah Studi Awal tentang Dasar-dasar Pendidikan pada Umumnya dan Pendidikan di Indonesia (Cet. 1; Jakarta: Raja Grafindo Persada, 2001), h.3.
} 
ditangani oleh pemerintah. Begitu juga tujuan endidikan telah dirumuskan dan ditetapkan sebagai standar dalam pelaksanaan pendidikan.Di Negara kita, pendidikan diarahkan untuk meningkatkan keimanan dan ketakwaan serta akhlak mulia dalam rangaka mencerdaskan kehidupan bangsa. $^{2}$

Untuk mewujudkan tujuan yang sangat ideal tersebut, maka pemerintah mengusahakan pendidikan.Bukan hanya pemerintah, tapi masyarakat ikut bertanggung jawab untuk itu.Masyarakat didorong untuk ikut ambil bagian dalam perwujudan cita-cita pendidikan yang telah dirumuskan itu.Maka muncullah sekolah-sekolah yang diselenggarakan oleh masyarakat, baik perorangan maupun berkelompok, di samping yang diselenggarakan oleh pemerintah (negatif).

Bagi umat Islam tujuan pendidikan yang telah dirumuskan secara Nasional itu merupakan suatu hal yang istimewah, di mana iman dan takwa yang merupakan tujuan pendidikan dalam Islam $^{3}$ dijadikan sebagai tujuan pendidikan Nasional. Dalam Islam tujuan pendidikan secara umum adalah dalam rangka pembentukan kepribadian muslim yang seutuhnya, yaitu pribadi yang ideal meliputi aspek individu, sosial dan intelektual. ${ }^{4}$ Pribadi yang seutuhnya merupakan sekumpulan cirri-ciri manusia yang baik, dilandasi oleh iman dan takwa kekhusyuan dan rasa malu. ${ }^{5}$

Kualitas pribadi tersebut meskipun secara hereditas telah tercakup dalam fitrah penciptaan manusia (QS.Al-Rum \{30\}:30) namun pengembangannya melalui jalan penanaman nilai budaya.

${ }^{2}$ Lihat UUD 1945 hasil amandemen bab XIII pasal 31 ayat (3) Lengkapnya tujuan pendidikan itu dirumuskan dalam UU No. 20 tahun 2003 Tentang Sistem Pendidikan Nasional pasal 3: "Pendidikan Nasional berfungsi mengembangkan kemampuan dan membentuk watak serta peradaban bangsa yang bermartabat dalam rangka mencerdaskan kehidupan bangsa, bertujuan untuk berkembangnya potensi peserta didik agar menjadi manusia yang beriman dan bertakwa kepada Tuhan yang Maha Esa, berakhlak mulia, sehat, cakap, kreatif, mandiri, dan menjadi warga Negara yang demokratis serta bertanggung jawab.”

${ }^{3}$ Ada yang meruuskan bahwa tujuan pendidikan Islam itu adalah untuk mewujudkan manusia yang bertakwa, memiliki kekhusyuan dan rasa malu. Lihat Muhammad Qutb, Sistem Pendidikan Islam, terjemahan Salman Harun (Cet. 1; Bandung: PT. Al-Ma'arif, 1984), h. 398. Yang lain merumuskan bahwa tujuan pendidikan Islam ialah terciptanya kepribadian muslim dengan indikator; jasmaninya sehat, kuat, dan berketerampilan; akalnya cerdas, yakni mampu menyelesaikan masalahnya secara cepat, tepat, ilmiah, filosofis, memiliki serta mengembangkan sains; dan hatinya bertakwa kepada Allah Swt, Lihat Ahmad Tafsir, Ilmu Pendidikan Islam Perspektif Islam ( Cet, 1; Bandung: Remaja Rosdakarya, 1992), h. 50-51.

${ }^{4}$ Abd. Rahman Getteng, Pendidikan Islam dalam Pengembangan Moral, Remaja, Wanita, dan Pembangunan (Makasar: Yayasan Al-Ahkam, 1997), h. 35.

${ }^{5}$ Muhammad Qutb, Sistem Pendidikan Islam, (Cet. 1; Bandung: PT. Al-Ma'rif, 1984), h. 398. 
Takwa merupakan kata kunci yang berdimensi teoritis dan praktis.Oleh karena itu, pendidikan Islam menekankan segi kemanfaatan ilmu. ${ }^{6}$ Sehingga menuntut ilmu adalah dalam rangka dimanfaatkan secara praktis maupun teoritis yang mengarahkan manusia kepada peningkatan keimanan kepada Allah Swt. Al-Qur'an menggariskan bahwa orang yang paling mulia hidupnya adalah mereka yang berilmu dan ilmunya dilandasi oleh Iman (QS. AlMujadalah \{58\}: 11). Begitu juga konsep ibadah dalam Islam dimaksudkan agar manusia menjadi bertakwa (QS. Al-Baqarah $\{2\}: 21)$.

Untuk mendapatkan kondisi seperti itu, pendidikan dalam Islam harus mampu mengantarkan peserta didik kepada mengintegrasikan nilai-nilai agama dalam perilaku. ${ }^{7}$ Artinya anak-anak itu didik agar setelah selesai mengikuti pendidikan mereka bisa menjadikan nilai-nilai agama sebagai ukuran dalam melaksanakan ibadah shalat harus dimaknai sebagai pernyataan dan membuktikan ketundukan kepada Allah.Maka apapun yang dilakukan dalam kehidupan ini selalu dalam bingkai ketundukan kepada-nya.Maka lembaga pendidikan dalam semua jalur, jenis dan jenjangnya ${ }^{8}$ bertanggung jawab mengusahakan pelaksanaan tugas itu.

Bila dicermati tujuan pendidikan itu mengarah pada perubahan perilaku dari tidak baik menjadi baik, dari negative menjadi positif, bukan sebaliknya. Sejak awal tumbuhnya kesadaran tentang adanya pendidikan dalam masyarakat telah diletakan suatu prinsip dasar bahwa pendidikan dimaksudkan untuk menanamkan budaya dengan jalan mengajarkan anak-anak untuk mengetahui serta mengamalkan nilai-nilai, norma-norma, atau tata cara baik yang berlaku dalam masyarakat. ${ }^{9}$

${ }^{6} \mathrm{Ilmu}$ yang bermanfaat adalah ilmu yang digunakan untuk kemaslahatan umat manusia sehingga manusia yang baik adalah yang paling bermanfaat bagi sesamanya.Sebaik-baik manusia adalah yang bermanfaat bagi umat manusia.

${ }^{7}$ Sebenarnya jika disadari bahwa dala agama itu sangat serat dengan nilai-nilai inversal, yaitu yaitu nilainilai yang berlaku dalam talanan, waktu, dan tempat manapun, serta merupakan kebutuhan masyarakat manapun.Dengan demikian, fungsionalisasi nilai-nilai tersebut harus secara fungsional menjadi bagian yang tak terpisahkan dari suatu sistem dalam kehidupan. Jusuf Amir Faisal, Reorientasi Pendidikan Islam, (Cet. 1; Jakarta: Cerna Insani Pres, 1995), h.185

8 Dalam Undang-undang No. 20 tahun 2003 Tentang Sistem pendidikan Nasional, istilah jalur pendidikan wahana yang dilalui peserta didik untuk mengembangkan potensi diri dalam suatu proses pendidikan yang sesuai dengan tujuan pendidikan (pasal 1 ayat 7). Jenis Pendidikan kelompok yang didasarkan pada kekhususan tujuan pendidikan suatu satuan pendidikan (pasal 1 ayat 9). Sedangakan jenjang pendidikan adalah tahapan pendidikan yang ditetapkan berdasarkan tingkat perkembangan peserta didik, tujuan yang akan dicapai, dan kemampuan yang akan dikembangakan (pasal 1 ayat 8).

${ }^{9}$ Menurut Hasan Langgulung, Pendidikan disamping mengusahakan pengembangan individu, ia juga mengusahakan pelestarian dan pewarisan budaya. Jadi, Pendidikan Islam adalah pengembangan potensi (fitrah) manusia dengan jalan pewarisan nilai budaya Islam dari generasi tua kepada generasi muda. Lihat Hasan Langgulung, Asas-Asas Pendidikan Islam (Cet.II; Jakarta: Pustaka Al-Husna, 1992), h 1-2. Selanjutnya, menurut 
Dari sini dipahami bahwa roh dari pendidikan itu adalah penanaman dan pewarisan nilai budaya.Kepribadian seseorang terbentuk karena adanya nilai-nilai budaya di mana seseorang dilahirkan, dibesarkan, dan didik.Tanpa nilai budaya tidak mungkin lahir suatu kepribadian. ${ }^{10}$

Berangkat dari penjelasan di atas, maka yang menjadi fokus masalah dalam makalah ini adalah bagaimana nilai-nilai dan budaya yang perlu dipertahankan sebagai hasil warisan pendidikan Islam pada kita sebagai generasi pelanjut?Bagaimana metode pendidikan Islam dalam pewarisan nilai-nilai dan budaya tersebut?

\section{B. NILAI-NILAI DAN BUDAYA YANG PERLU DIPERTAHANKAN SEBAGAI HASIL WARISAN PENDIDIKAN}

Sebelum lebih jauh membahas mengenai pewarisan nilai-nilai dan budaya, terlebih dahulu penulis akan menjelaskan pengertian nilai dan budaya yang dimaksud dalam makalah ini.

Kata value yang kemudian diterjemahkan dalam bahasa Indonesia menjadi nilai, berasal dari bahasa latin yaitu valere, atau bahasa Prancis kuno volair yang berarti (berguna, mampu akan, berdaya, berlaku, kuat). ${ }^{11}$

Dalam sudut pandangan filosofia, nilai sangat terkait dengan masalah etika.Etika juga sering disebut sebagai filsafat nilai, yang mengkaji nilai-nilai moral sebagai tolak ukur tindakan dan perilaku manusia dalam berbagai aspek kehidupan. ${ }^{12}$ Hal ini bisa dilihat dalam Kamus Besar Bahasa Indonesia, bahwa nilai merupakan sesuatu yang menyempurnakan manusia sesuai dengan hakikatnya, ini berhubungan erat dengan etika., yang artinya nilai untuk manusia sebagai pribadi yang utuh, misalnya kejujuran, nilai yang berhubungan dengan akhlak, nilai yang berkaitan dengan benar dan salah. ${ }^{13}$ Pengertian ini semakin diperkuat dalam Ensiklopedia pendidikan diterangkan bahwa nilai adalah filsafat tentang baik dan buruk, yang mengajarkan tentang keluruhan budi. ${ }^{14}$ Sedangkan menurut istilah nilai adalah studi tentang tingka laku

beliau, budaya itu bisa mati seperti layaknya manusia yang mati apabila nyawanya putus.Budaya disebut mati bila nilai-nilai, norma-norma, dan berbagai unsure lainnya berhenti berfungsi, artinya tidak dilestarikan denga jalan diwariskan dari generasi kegenerasi dan tidak lagi di amalkan dalam kehidupan sehari-hari. Hasan Langgulung, Pendidikan Islam Menghadapi Adap 21 (Cet. !; Jakarta Pustaka Al-Husna, 1998), h. 61-62

${ }^{10}$ Lihat H.A.R, Paradigma Baru Pendidikan Nasional (Cet. II; Jakarta: Rineke Cipta, 2004), h. 190.

${ }^{11}$ Lorenz bagus, Kamus Filsafat (Cet, 3; Jakarta: Gramedia, 2002), h. 713.

${ }^{12}$ Said Aqil Husin Almunawar, Aktualisasi Nilai-nilai Qurani dalam Sistem Pendidikan Islam (Cet; Jakarta : Ciputat Press, 2003), h. 3.

${ }^{13}$ Tim Penyusun Kamus Pusat Bahasa, Kams Besar Bahasa Indonesia, (Cet. 3; Jakarta: balai Pustaka, 2005), h. 783.

${ }^{14}$ Soegarda Poerbawatja, Ensiklopedi Pendidikan, (Jakarta: Gunung Agung, 1999), h. 82 
manusia, tidak hanya menentukan kebenaran sebagaimana adanya, tetapi juga menelidiki manfaat atau kebaikan dari seluruh tingka laku manusia yaitu perilaku yang melandasi moralitas tingka laku manusia yaitu perilaku yang melandasi moralitas (akhlak). ${ }^{15}$ Ada juga yang mengartikan nilai adalah suatu keyakinan yang membuat seseorang atas dasar pilihannya. ${ }^{16}$

Sedangakan menurut Hans Jonas nilai adalah patokan normative (pertimbangan baik dan buruk, benar dan salah, haq dan batil, diridhai dan dikutuk oleh Allah) yang mempengaruhi manusia dalam menentukan pilihannaya diantara cara-cara tindakan alternative. ${ }^{17}$

Beberapa pengertian nilai diatas, pada intinya bahwa nilai adalah rujukan dan keyakinan dalam menentukan suatu pilihan bagi seseorang, yang tercermin dalam pola pikir, tingkah laku, dan serta sikap.Seperti kejujuran, keadilan, kebenaran dijadikan sebagai pegangan dalam hidupnya.

Sedangakan budaya, yang lazim disebut kebudayaan atau system kebudayan, berasal dari kata sansekerta buddhayah, yaitu bentuk jamak dari buddhi yang berarti "budi" atau "akal". Dari penertian kata biddhi itulah, kebudayaan dapat diartikan sebagai "hal-hal yang bersangkutan dengan akal". ${ }^{18}$ Dalam definisi yang klasik tentang kebudayaan sebagaimana di kemukakanoleh Edwar Burnett Tylor pada abad ke-19, secara jelas dinyatakan bahwa budaya merupakan suatu keseluruhan yang kopleks yang mencakuppengetahuan, keyakinan, kesenian, moral, hukum adat istiadat dan segala kemampuan dan kebiasaan yang diperoleh manusia sebagai anggota masyarakat. ${ }^{19}$

Dari definisi tentang budaya di atas, kita dapat mengatakan bahwa budaya tidak hanya keluhuran ide-ide yang dimiliki manusia melalui proses belajar, tetapi juga tingka laku manusia yang berpola yang menjadi landasannaya, dan hasi manusia berupa benda-benda fisik. Sesuai dengan pengertian ini, maka hampir semua tingkah laku manusia dapat diklasifikasikan sebagai budaya, karena sedikit saja tindakan manusia yang tidak perlu dipelajari. Misalnya gerakan reflex kedipan mata tidak tergolong budaya. Karena merupakan tingkah laku melirik yang harus dipelajari oleh si penari.

\footnotetext{
${ }^{15}$ Kaheruddin, Pemikiran Nilai dan Etika Pendidikan Islam (Cet, 1; Makasar Yayasan Pendidikan Makasar, 2003), h. 63.

${ }^{16}$ Rohman Mulyana, Mengartikulasikan Pendidikan Nilai (Cet, 1; Bandung Alfabeta, 2004), h. 9

${ }^{17}$ Ibid.

${ }^{18}$ Redaksi Ensiklopedi Nsional, Ensiklopedi Nasional Indonesia, jilid III (Cet. 1; Jakarta : PT. Cipta Adi Pustaka, 1998), h. 495.

${ }^{19}$ Ibid.
} 
Lain halnya pendapat Ki Hajar Dewantara, Agus Salim, dan berapa budayawan lainnya, yang mengatakan budaya itu adalah gabungan dari kata "budi" dan "daya". Budi terletak di hati, daya terletak diperbuatan.Iman timbalan budi, amal timbalan daya. ${ }^{20}$

Kalau demikian, definisi budaya menurutnya adalah penjelmaan iman dan amal saleh dari seorang muslim atau segolongan kaum muslimin. Dengan alasan amal saleh ialah tingkah laku yang sesuai dengan iman. Karena muslim beriman kepada Allah, ditaati segalah perintahnya dan menjauhi segala larangannya. Maka perbuatan karna iman itulah yang disebut amal saleh.Sebab itu amal saleh meliputi dua bidang yaitu agama dan budaya. Karena itu tidaklah tepat untuk mengartikan budaya sebagai penjelmaan iman dan amal saleh, kalau amal saleh itu kebudayaannya sendirinya agama termasuk dalam bidang budaya. ${ }^{21}$ Jadi inti dari istilah nilai budaya adalah suatu konsep abstrak mengenai masalah dasar yang sangat penting dan bernilai dalam kehidupan manusia. Konsep tersebut dapat berupa nilai etik, seperti sopan santun, nilainilai tersebut tentunya yang sesuai dengan semangat ajaran islam.

Terlepas dari pengertian di atas, selanjutnya bagaimana pendidikan Islam dikatakan sebagai pewaris nilai-nilai dan budaya. Pada hakikatnya, dilihat dari segi identitas sosio-kultural muslim, pendidikan merupakan pembudayaan umat manusia yang paling diperlukan di antara keperluan hidupnya, meskipun pendidikan itu sendiri pada mulanya timbul dan berkembang dari sumber kultur umat itu sendiri. ${ }^{22}$

Sebagai suatu alat, maka pendidikan Islam harus harus memiliki watak lentur terhadap perkembangan aspirasi kehidupan manusia sepanjang zaman.Watak demikan dengan tanpa menghilangkan prinsip-prinsip nilai yang mendasarinya.Pendidikan Islam maupun mengakomodikasikan tuntutan hidup manusia dari zaman ke zaman, termasuk tuntutan di bidang teknologi. ${ }^{23}$

Khusunya berkaitan dengan tuntutan perkembangan ilmu dan teknologi, pendidikan Islam, bersikap mengarahkan dan mengendalikannya, sehingga nilai fundamental yang bersumber dari iman dan takwa kepada Allah, dapat berfungsi dalam kehidupan manusia yang telah menciptakan ilmu dan teknologi itu. Iman dan takwanya menjiwai ilmu dan teknologi yang

\footnotetext{
${ }^{20}$ Sidi Gazalba, Asas Kebudayaan Islam Pembahasan Ilmu dan filsafat Tentang Ijtihad, Fiqih, Akhlak, Bidang-bidang Kebudayaan, Masyarakat, Negara, (Cet 1; Jakarta: Bulan Bintang, 1978), h. 168.

${ }^{21}$ Ibid.

${ }^{22}$ M. Arifin, Filsafat Pendidikan Islam (Cet. IV; Jakarta : Bumi Aksara, 1994), h. 36.

${ }^{23}$ Ibid.
} 
diciptakan, sehingga penggunaannya pun diarahkan kepada upaya menciptakan kesejahteraan hidup umat manusia, bukan untuk menghancurkannya. ${ }^{24}$ Karena iman dan takwa kepada Allah ada hakikatnya merupakan rujukan tingkah laku manusi yang memancarkan getaran hati nurani manusia yang berkecenderungan kearah perikemanusiaan. Dengan demikian, manusia muslim hasil pendidikan adalah manusia yang berkemampuan menguasai dan menciptakan ilmu dan teknologi pada khususnya, dan sistem budaya hidupnya berdasarkan nilai-nilai Islami yang berorientasi kepada kesejahteraan hidup di dunia untuk meraih kebahagiaan hidup di akhirat.

Ada tiga dimensi kehidupan manusia yang mengandung nilai ideal Islam dan dijadikan dasar fundamental dari proses pendidikan Islam yaitu:

1. Dimensi yang mengandung nilai yang meningkatkan kesejahteraan hidup manusia di dunia. Dimensi nilai kehidupan ini mendorong kegiatan manusia untuk mengelolah dan memanfaatkan dunia ini agar menjadi bekal/sarana bagi kehidupan di akhirat.

2. Dimensi yang mengandung nilai yang mendorong manusia berusaha keras untuk meraih kehidupan di akhirat yang membahagiakan. Dimensi ini menurut manusia untuk tidak terbelenggu oleh rantai kekayaan duniawi atau materi yang dimiliki, namun kemelaratan atau kemiskinan dunia harus berantas, sebab kemelaratan atau kemiskinan dunia harus di berantas, sebab kemelarantan duniawi bisa menjadi acaman yang menjerumuskan manusia kepada kekufuran.

3. Dimensi yang mengandung nilai yang dapat memadukan antara kepentingan hidup duniawi dan ukhrawi. Keseimbangan dan keserasian antara kedua kepentingan hidup ini menjadi daya tangkal terhadap pengaruh-pengaru negatif dari berbagai gejolak kehidupan yang menggoda ketenangan hidup manusia, baik yang bersifat spritual, sosial, kultural, ekonomis, maupun idelogis dalam hidup manusia. ${ }^{25}$

Dimensi-dimensi nilai di atas merupakan sasaran idealitas Islami yang seharusnya dijadikan dasar fundamental dari proses kependidikan Islam. Dimensi-dimensi nilai tersebut seharusnya ditanam-tumbuhkan di dalam pribadi muslim secara seutuhnya melalui proses pembudayaan yang bercorak pendidikan dengan sistem atau struktur kependidikan yang bagaimanapun bentuknya.

\footnotetext{
${ }^{24}$ Ibid., h. 37
}

${ }^{25}$ Ibid., h. 120 
Disinilah kita menilai bahwa, dimensi nilai-nilai Islami yang menekankan keseimbangan dan keselarasan hidup duniawi-ukhrawi, menjadi landasan ideal yang hendak dikembangkan atau dibudayakan dalam pribadi manusia melalui pendidikan sebagai alat pembudayaan.

Nilai-nilai Islami yang fundamental yang mengandung kemutlakan bagi kehidupan manusia, selaku pribadi dan selaku anggota masyarakat tidak berkecenderungan untuk berusaha mengikuti selera bafsu manusia yang berubah-ubah sesuai tuntutan itu, sebaliknya akan berfungsi sebagai pengendali atau pengarah terhadap tuntutan perubahan sosial dan tuntutan individual. ${ }^{26}$

Disinilah tugas pendidikan Islam, untuk dapat mempertahankan, menanamkan, dan mengembangkan kelangsungan berfungsinya nilai-nilai Islam bersumber dari Al-Qur'an dan Hadis. Dan sejalan dengan tuntutan kemajuan kehidupan masyarakat akibat pengaruh kebudayaan yang meningkat. ${ }^{27}$

Jika hal ini dapat berjalan dengan pendidikan Islam, maka tujuan dari pendidikan Islam akan tercapai. Artinya seseorang yang berhasil dididik menjadi muslim, sudah barang tentu memiliki dalam pribadinya suatu pola hidupnya diwarnai oleh nilai-nilai Islami secara utuh dan bulat. Nilai-nilai itu akan nampak dalam perilaku kehidupan lahiriah sebagai refleksi dari perilaku batiniahnya. Perilaku batiniahnya senantiasa berorientasi kepada norma-norma ajaran Islam yang mengacuh kedalam nilai-nilai Islami yang membentuk sikap dan perilakunya sehari-hari. Dengan kata lain, jiwa Islami telah menjadi sumber rujukan dari perilaku seseorang muslim sejati dalam hidupnya.

Di atas telah di uraikan bahwa, tujuan pendidikan Islam merupakan cita-cita ideal yang mengandung nilai Islami terhadap proses kependidikan, tetntuh kita bertanya nilai-nilai apakah yang di cita-citakan dari tujuan itu agar dapat mewarnai corak kepribadian manusia dari hasil proses kepribadian. Indonesia sebagai Negara yang berfalsafah pancasilah menetapkan tujuan pendidikan adalah untuk meningkatkan ketakwaan terhadap Tuhan Yang Maha Esa, kecerdasan dan keterampilan, mempertinggi budi pekerti, memperkuat kepribadian dan mempertebal semangat kebangsaan dan cinta tanah air, agar dapat menumbuhkan manusia-manusia pembangun yang dapat membangun dirinya sendiri serta bersama-sama bertanggung jawab atas pembangunan bangsa. ${ }^{28}$

\footnotetext{
${ }^{26}$ Ibid., h. 121.

${ }^{27}$ Ibid.

${ }^{28}$ Amai Arif, Reformulasi Pendidikan Islam (Cet. 1; Jakarta: CRSD Press 2008), h. 19.
} 
Dalam rumusan tujuan di atas nampak jelas bahwa nilai-nilai yang hendak ditumbuhkembangkan dalam pribadi anak didik adalah nilai-nilai kultur bangsa Indonesia yang bercorak sosialitasreligius, yaitu semangat kegotong-royongan yang dijiwai oleh nilai-nilai keagamaan. Dalam hal ini tidak mengkhususkan nilai agama tertentu. Sedangakan faktor-faktor kognitif, afektif, psikomotorik yang dilandasi dengan moralitas yang tinggi menjadi potensi fundamental bagi perkembangannya dalam hidup bernegara dan berbangsa yang bertanggung jawab. ${ }^{29}$

Selain itu, menurut Mohd. Fadhil al-Djamaly, sasaran pendidikan menurut Al-Qur'an adalah membina pengetahuan kesadaran atas dirinya, dan atas sistem kemasyarakatan Islami serta atas sikap dan rasa tanggung jawab sosial, juga memberikan kesadaran manusia terhadap alam sekitar dan ciptaan Allah serta mengembangkan ciptaan-Nya bagi kebaikan menurut beliau adalah makrifat kepada pencipta alam dan beribadah kepadanya dengan cara mentaati perintah-perintah dan menjauhi segala larangan-Nya. ${ }^{30}$

Dengan demikian tujuan pendidikan Islam menurut pendapat di atas, sesuai dengan nilai-nilai Islam yaitu dengan menanamkan kesadaran dalam diri manusia terhadap dirinya sendiri selaku hamba Allah, dan kesadaran selaku anggota masyarakat yang harus memiliki rasa tanggung jawab sosial terhadap pembinaan masyarakat serta menanamkan kemampuan manusia untuk mengelolah, memanfaatkan alam sekitar ciptaan Allah bagi kepentingan kesejahteraan manusia dan kegiatan ibadahnya kepada khalik pencipta alam itu sendiri.

Jelaslah bahwa di dalam proses kependidikan yang dikehendaki oleh Islam untuk mencapai sasaran dan tujuan akhir, nilai-nilai Islami akan mendasari dan lebih lanjut akan membentuk corak kepribadian anak didik, pada masa dewasanya.

Dengan kata lain, pendidikan Islam secara filosofis berorientasi kepada niali-nilai Islami yang bersasaran pada tiga dimensi hubungan manusia selaku khalifah di muka bumi yang sebagai berikut:

1. Menanamkan sikap hubungan yang seimbang, selaras, serasi dengan tuhannya.

2. Membentuk sikap hubungan yang harmonis, selaras, seimbang dengan masyarakatnya.

3. Mengembangkan kemampuannya untuk menggali, mengelolah dan memanfaatkan kekayaan alam ciptaan Allah bagi kepentingan kesejahteraan hidupnya, dan hidup sesamanya serta bagi

\footnotetext{
${ }^{29} \mathrm{Ibid}$.

${ }^{30} \mathrm{M}$. Arif, op.cit, h. 133.
} 
kepentingan ubudiyahnya kepadanya, dengan dilandasi sikap hubungan yang harmonis pula. $^{31}$

Sikap hubungan yang harmonis itulah yang perlu ditanamkan dalam pendidikan Islam, baik hubungan kita kepada Allah, manusia, serta alam semesta.

Hasan Langgulung berpendapat bahwa nilai akhlaklah yang perlu dimiliki oleh manusia untuk keselamatan dan kebahagiaan di dunia dan diakhirat. Nilai-nilai ini dapat dikategorikan dalam lima kategori yaitu:

1. Nilai akhlak perseorangan

2. Nilai akhlak kekeluargaan

3. Nilai akhlak sosial

4. Nilai akhlak kenegaraan

5. Nilai akhlak keagamaan. ${ }^{32}$

Dari lima diatas intinya adalah takwah. Dengan kata lain takwa itulah himpunan nilai-nilai yang ada dalam Islam. Seperti tergambar dalam (QS. Al-Baqarah \{2\}: 1-5).

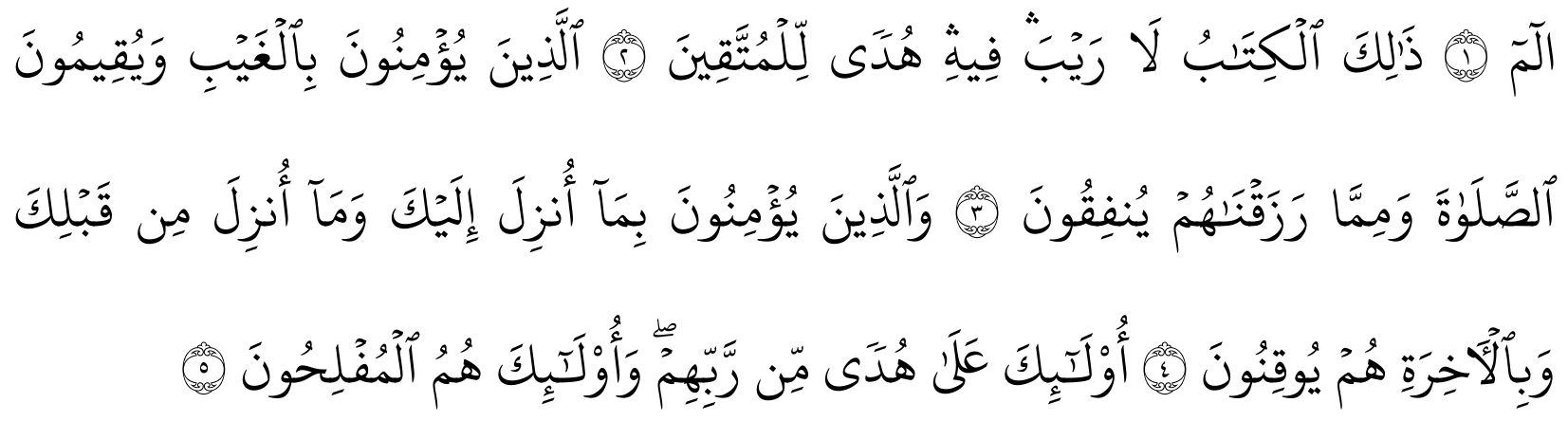

Alif laam miin. Kitab (Al Quran) ini tidak ada keraguan padanya; petunjuk bagi mereka yang bertaqwa. (yaitu) mereka yang beriman kepada yang ghaib, yang mendirikan shalat, dan menafkahkan sebahagian rezki yang Kami anugerahkan kepada mereka. Dan mereka yang beriman kepada kitab (Al Quran) yang telah diturunkan kepadamu dan Kitab-Kitab yang telah diturunkan sebelummu, serta mereka yakin akan adanya (kehidupan) akhirat. Mereka Itulah yang tetap mendapat petunjuk dari Tuhan mereka, dan merekalah orang-orang yang beruntung.

Sedangkan menurut Said Agil Husin Almunawar, dengan melihat masyarakat dinamis sebagai akibat kemajuan ilmu dan teknologi informasi, maka aktualisasi kitab suci, umat Islam

\footnotetext{
${ }^{31} I$ Ibid., h. 134.

${ }^{32}$ Hasan Langgulung, Peralihan Paradigma dalam Pendidikan Islam dan Sains Sosial (Cet. 1; Jakarta: Gayah Media Pratama, 2002), h. 101.
} 
akan menghadapi kendala dalam upaya internalisasi nilai-nilai Qurani sebagai upaya pembentukan pribadi umat yang beriman, bertakwa, berakhlak mulia, cerdas, maju dan mandiri. Tujuan yang dicapai dalam proses aktualisasi nilai al-Qur'an dalam pendidikan meliputi tiga dimensi kehidupan yang harus di bina dan dikembangkan oleh pendidikan Islam yang pertama, dimensi spritual, yaitu iman, takwa, dan akhlak mulia (yang tercermin dalam ibadah dan muamalah) kedua,dimensi budaya, yaitu kepribadian yang mantap dan mandiri, tanggung jawab kemasyarakatan dan kebangsaan. Ketiga,dimesi kecerdasan yang membawa kepada kemajuan, yaitu cerdas, kreatif, terampil, disiplin, etos kerja, penghargaan akan waktu, profesional,inovatif dan produktif. ${ }^{33}$

Dalam upaya aktualisasi nilai-nilai Qurani, maka peran keluarga harus dilakukan, disamping memperkuat lembaga pendidikan formal. Dengan demikian, tanggung jawab akan di pikul bersama oleh guru, orang tua, dan masyarakat.

Jadi intinya, antara tujuan pendidikan Islam dengan nilai-nilai pendidikan Islam harus saling berkaitan dengan erat nilai-nilai tersebut merupakan proses kependidikan yang di inginkan, namun yang paling penting dalam proses kependidikan ini adalah, nilai yang oleh setiap orang di usahakan secara sunggu-sunggu untuk merealisasikanya melalui pendidikanya. Nilai-nilai itu adalah yang terwujud dalam keseluruhan hidup pribadi dan sosial manusia. Nilai-nilai yang mampu mempengaruhi, memberi corak dan watak kepribadian yang berkembang sepanjang hayatnya.

Pada intinya nilai yang ingin dicapai dari hasil pendidikan menurut Zakiah Darajat ${ }^{34}$ ada empat, yaitu: 1) Nilai material, 2) Nilai formal, 3) Nilai fungsional, dan 4) Nilai esensial. Yang dimaksud dengan nilai material di sini adalah, jumlah pengetahuan Islam yang diajarkan. Semakin lama siswa belajar semakin bertambah ilmu pengetahuan agamanya. Pertambahan bahan itu berlangsung melalui kelas demi kelas dalam suatu lembaga pendidikan, bagi mereka yang melanjutkan pendidikan. ${ }^{35}$

Ilmu pengetahuan adalah alat yang harus dimiliki manusia, jika ia hendak mencapai kesempurnaan dirinya. Disini peran ilmu agama berperan sebagai alat untuk mengantarkan manusia melalui pemahaman dan penggunaan ilmu tersebut, untuk meningkatkan ketakwaan

\footnotetext{
${ }^{33}$ Said Agil Husin Almunawar, op.cit., h. 6-7.

${ }^{34}$ Zakiah Darajat, Metodik Khusus Pengajar Agamai Islam (Cet III; Jakarta: Bumi Aksara, 2004), h. 192.

${ }^{35}$ Ibid.
} 
kepada Allah Swt. Di tinjau dari segi aspek pengajaran agama Islam, pertambahan ilmu agama Islam berarti pertambahan pada setiap aspeknya dan bermakna, semakin bertambah ilmu pengetahuan agama semakin besar peluang untuk mencapai keridahaan Allah Swt.

Nilai formal adalah nilai pembentukan, yang bersangkutan denga daya serap siswa atas segala bahan yang telah diterimanay. Hal itu berarti sejauh manakah daya serap siswa, sehingga ia mampu dengan tenaganya sendiri membentuk kepribadian yang utuh, kokoh dan tahan uji. Sedangkan maksud nilai fungsional disini adalah relevansi bahan dan kehidupan sehari-hari. Jika bahan itu mengandung kegunaan, dapat dipakai atau berfungsi dalam kehidupan sehari-hari, maka itu berarti mempunyai nilai fungsional. ${ }^{36}$

Yang dimaksud dengan nilai esensial ialah nilai hakiki. Agama mengajarkan bahwa kehidupan hakiki atau hidup yang sebenar-benar hidup itu berlangsung di alam baqa. Jadi kehidupan itu tidak berhenti hingga di dunia saj, melainkan kehidupan itu berlangsung terus di alam akhirat. Kematian merupakan permulaan kehidupan hakiki itu, sebagai pembeda antara dua kehidupan yang merupakan suatu keseluruhan hidup dan tidak terpisahkan. Pergantiannya laksana pengertian siang dan malam dalam suatu kesatuan hari.

Ketiga nilai yang telah di uraikan diatas, mengandung nilai-nilai ajaran bagi manusia dalam menempuh seluruh kehidupan manusia berisi dua yaitu dunia dan akhirat. Gambaran kehidupan dunia pada umumnya dapat dihayati dan dijangkau oleh akal manusia. Tidak demikian halnya dengan gambaran kehidupan akhirat, manusia mengenalnay semata-mata melalui wahyu ilahi. Wahyu mendekatkan jangkauan akal, untuk mengahayatinya diperlukan kebersihan atau kesucian roh atau jiwa. Yang cara-caranya ditunjukan oleh agama, melalui pemeliharaan hubungan dengan manusia, semakin dekat dan ikhlas pelaksanaan pemeliharan itu, semakin meningkat pula ketakutan manusia kepada-Nya.

Dengan demikian, seluruh nilai-nilai pengajaran agama itu bermuara pada nilai hakiki atau nilai esensial yang berbentuk yaitu:

1. Nilai pembersihan atau pensucian rohani/jiwa, yang memungkinkan seseorang siap untuk menerima, memahami dan menghayati ajaran agama Islam sebagai pandangan hidupnya.

2. Nilai kesempurnaan akhlak, yang memungkinkan seseorang memiliki al-Akhlaq al-Karimah, yang tercermin pada sifat-sifat Nabi Muhammad Saw. Dan mengamalkannya ajaran agama Islam secara sempurna sepanjang hayatnya.

${ }^{36}$ Ibid., h.. 193-194. 
3. Nilai peningkatan takwa kepada Allah Swt, sehingga diri seseorang menjadi semakin akrab kepadanya dan dengan penuh gairah serta ketulusan hati menyongsong kehidupan yang hakiki. $^{37}$

4. Dengan demikian, dalam pendidikan Islam nilai yang perlu diwariskan itu tidak lain adalah nilai-nilai yang terdapat dalam sumber ajaran Islam, yakni Al-Qur'an dan Sunnah. Nilai-nilai tersebut mencakup aspek kepribadian manusia sebagai individu dan sebagai anggota masyarakat. Oleh karana itu, nilai-nilai yang berkembang dalam masyarakatsepanjang tidak bertentangan dengan ajaran Islam adalah termasuk nilai-nilai budaya yang perlu dilestarikan. Dan inti dari nilai-nilai itu sebenarnya tersimpul dalam al-Akhlaq al-Karimah (QS. Al-Qalam \{68\}: 4), atau budi pekerti. ${ }^{38}$ Kesanalah muara dari dalam bentuk apapun, baik pengetahuan, pelatihan keterampilan/keahlian tertentu, maupun bimbingan-bimbingan mental kerohanian (aspektif).

Pencapaian dari salah satu unsure mupun yang menonjol dari potensi anak didik itu harus bermuatan budi pekerti. Budi pekerti sebenarnaya merupakan suatu konsep nilai yang abstrak. Penampakanya haya ada dalam seluruh gerakan motorik da ekspresi afektif dan kognitif seseorang. Dengan kata lain, budi pekerti seseorang hanya dapat diketahui bila mana seseorang itu melakukan interaksi dengan lingkungannya, baik lingkungan fisik-material maupun lingkungan sosila.

Dalam dunia pendidikan (formal) lingkungan sosialnya adalah para mahasiswa, para guru, dan pegawai sekolah. Sedangkan lingkungan fisik/materialnya adalah sarana dan prasarana sekolah. Ketika seseorang siswa berinteraksi dengan kedua lingkungan itu segera diketahui bagaimana akhlaknya.

\section{METODE PENDIDIKAN ISLAM DALAM PEWARISAN NILAI-NILAI DAN BUDAYA}

Dalam proses kependidikan itu, menyangkut internalisasi nilai-nilai Islam dimana faktor iman dan takwa menjadi tujuannya, maka prosesnya lebih memerlukan pengarahan yang kuat, iman dan takwanya dalam pribadi manusia mengandung tenensi naik turun sebagaimana

\footnotetext{
${ }^{37}$ Ibid., h. 196.

${ }^{38}$ Muhammad Athiyah al-Abrasyi, al-Tarbiyah al-Islamiyah, Terjemahan Bustami A. Gani dan Djohar bahry, Dasar-dasar Pokok Pendidikan Islam (Cet. 7; Jakarta: Bulan Bintang, 1993), h. 1.
} 
semangat atau dorongan batin lainnya. Maka dari itu pemantapannya memerlukan motivasi dan persuasi yang perpusat pada pribadinya. ${ }^{39}$

Untuk memperkokoh iman dan takwanya kepada Allah dapat dipergunakan melalui observasi dan belajar dalam pengalaman. Karena dalam Islam terdapat banyak ungkapan firman Tuhan yang menyatakan bahwa pengalaman panca idra hendaknay digunakan sepenuhnya untuk meneliti gejala alam raya dan kejadian diri manusia sendiri guna mengukuhkan kebenaran tentang adanya maha kuasa yang Esa, pencipta alam dan manusia. ${ }^{40}$ Firman Allah dibawah ini merupakan bukti bahwa melalui observasi dan studi alamiah, manusia akan menemukan Tuhannya. (QS. Al-Ghasiyah \{88\}: 17-20):

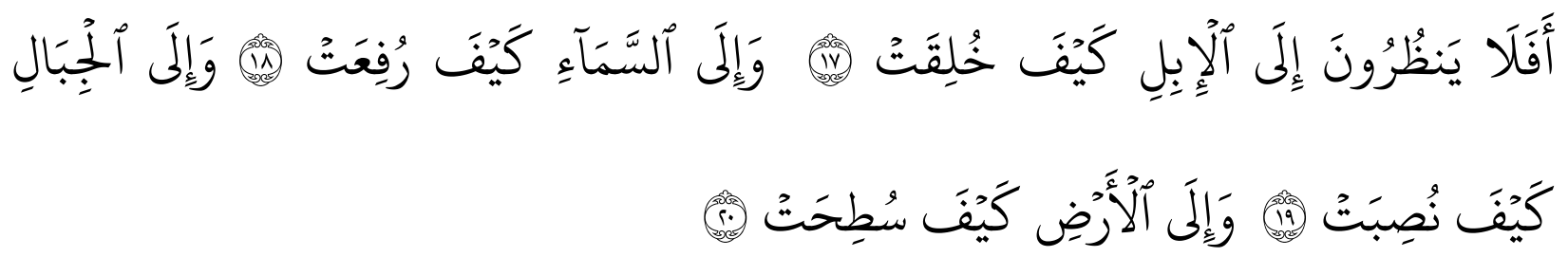

Maka Apakah mereka tidak memperhatikan unta bagaimana Dia diciptakan; dan langit, bagaimana ia ditinggikan; dan gunung-gunung bagaimana ia ditegakkan; dan bumi bagaimana ia dihamparkan. (QS. Al-Ghasiyah \{88\}: 17-20.

Disamping itu faktor pembiasaan dan keteladan juga yang dapat digunakan untuk pembinaan iman dan takwa, itu dilakukan karena adanya pengahayatan terhadap nilai-nilai Al-Qur'an yang dapat melahirkan keyakinan, sikap, perilaku, dan akhlak mulia. ${ }^{41}$

Pertanyaan ini merupakan salah satu jenis proses belajar ${ }^{42}$, di mana manusia-manusia atau hal-hal tertentu menjadi perangsang bagi seseorang untuk mengamalkan atau menghayati nilainilai dan perbuatan itu.

Dalam proses penghayatan nilai-nilai Islam, ada cara tertentu yang harus dipakai untuk menuju penghayatan itu. Cara ini disebut tazkiyah al-nafs (pemurnian jiwa). ${ }^{43}$ Tazkiyah al-nafs ini dapat diamalkan melalui ibadah-ibadah fardu dan sunnah seperti sembahyang, zakat, puasa, haji, tilawah al-Qur'an, muhasabah dan lain-lain yang sesuai dengan syarat-syarat.

\footnotetext{
${ }^{39}$ M. Arifin, op.cit, h. 126.

40 Ibid.

${ }^{41}$ Said Agil Husin Almunawar, op,cit., h. 15.

${ }^{42}$ Hasan Langgulung, “Asas-Asas...”, op.cit, h. 371.

${ }^{43}$ Ibid.
} 
Kalau ini dijadikan dengan betul maka kesannya akan tersa dalam gerak hati kita dalam bentuk tauhid, ikhlas dalam berbuat, sabar, syukur, dan lain-lain. Dan juga terhindar dari penyakt-penyakit jiwa seperti riya, nifaq, sombong, hasad, dengki dan lain-lain yang bukan hanya pada tingkah laku individu, tetapi dalam keluarga, tetangga-tetangga, masyarakat dan Negara.

Mohammad Fadlih al-Djamaly, ahli pendidikan Tinisia, berkesimpulan bahwa untuk mempertahankan nilai-nilai Islam, maka ada tiga sasaran strategi pendidikan Islam yang harus diserahkan yaitu:

1. Pengembangan iman sehingga benar-benar berfungsi sebagai kekuatan pendorong kea rah kebahagiaan hidup yang dihayati sebagai suatu nikmat paling besar yang dianugrahkan Allah kepada manusia. Iman adalah dasar dari nilai-nilai dan moral manusia yang diperkokoh perkembangannaya melalui pendidikan.

2. Pengembangan kemampuan mempergunakan akal kecenderunaan untuk menganalisa hal-hal yang berbeda dibalik kenyataan alam yang Nampak. Kemampuan akal kecerdasan diciptakan Allah dalam diri manusia agar dipergunakan untuk mengungkapkan perbedaan tentang yang baik, perkara yang hak dari yang batil. Dengan akal kecerdasan manusia akan mampu menempuh jalan yang benar. Allah memberikan kepada manusia 2 jalan yaitu jalan kebaikan dan jalan sosial. Seperti firmannya:

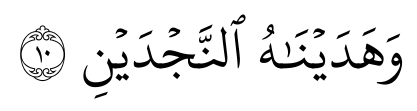

Dan Kami telah menunjukkan kepadanya dua jalan. (QS. Al-Balad \{90\}: 10).

Yang dimaksud dengan dua jalan ialah jalan kebajikan dan jalan kejahatan.

Pengembanagn potensi yang berakhlak mulia dan kemempuan berkomunikasi dengan orang lain, baik dengan ucapan maupun dengan perbuatan. Fitrah manusia yang suci mempunyai kecenderungan kepada kebaikan yang diyatakan melalui lisan dan perbuatan dengan cara lemah lembut. Mengenai cara berkomunikasi seorang muslim dengan orang lain, Allah memberikan petunjuk dasar yang mengandung nilai sosial yang lebih mengutamakan orang lain pada perasaan pribadinya sendiri.

3. Mengembangkan sikap beramal saleh dalam setiap pribadi muslim. Manusia diberi kemampuan oleh Allah untuk mampu berbuat kebaikan, menjaga diri, bekerja sama dan 
bergaul dengan orang lain demi kemaslahatan masyarakat. Untuk tujuan itu, manusia senang mempelajari hal-hal yang dapat menghasilkan kehidupan yang mulia, membina kehidupan keluarga sejahtera. Dari sikap positif demikian, manusia bersedia menghormati tata tertib sosial yang akan menjamin kehidupan, kebebasan dan hak-haknya, sehinnga terwujud keadilan, kejujuran dan kasih sayang. Konsekuensinya ialah orang-orang yang lemah, anak yatim, fakir miskin dan sebagainya mendapatkan santunan dari mereka yang kuat, si kaya, dan yang memegang kekuasaan. ${ }^{44}$

Oleh karena itu, dalam proses pendidikan, strategi di atas amat perlu diperhatikan, agar nilainilai dan budaya dalam Islam tetap dimiliki, serta dapat dipertahankan.

\section{KESIMPULAN}

Dari uraian di atas, dapatlah di pahami bahwa roh dari pendidikan itu adalah penanaman dan pewarisan nilai budaya. Kepribadian seseorang terbentuk karena adanya nilai-nilai budaya dimana seseorang dilahirkan, dibesarkan, dan dididik. Tanpa nilai budaya tidak mungkin lahir suatu kepribadian.

Dalam pendidikan Islam nilai yang perlu diwariskan itu tidak lain adalah nilai-nilai yang terdapat dalam sumber ajaran Islam, yakni Al-Qur'an dan sunnah. Nilai-nilai tersebut mencapai aspek kepribadian manusia sebagai individu dan anggota masyarakat. Oleh karena itu, nilai-nilai yang berkembang dalam masyarakat sepanjang tidak bertentangan dengan semangat ajaran Islam adalah termasuk nilai-nilai budaya yang perlu dilestarikan. Dan inti dari nilai-nilai itu sebenarnaya tersimpul dalam al-akhlaq al-karimah (QS. al-Qalam \{68\}: 4), atau budi pekerti. Ke sanalah muara dari segenap aktifitas pendidikan. Maka pelajaran yang diberikan dalam bentuk apapun, baik pengajaran ilmu pengetahuan, pelatihan keterampilan/keahlian tertentu, maupun bimbingan-bimbingan mental kerohanian (afektif).

Pencapaian dari salah satu unsur manapun yang menonjol dari potensi anak didik itu harus bermuatan budi pekerti.budi pekerti sebenarnya. Merupakan suatu konsep nilai yang abstrak. Penampakannya hanya ada dalam seluruh gerakan mentorik dan ekspresi afektif dan kognitif seseorang. Dengan kata lain, budi pekerti seseorang. Dengan kata lain, budi pekerti seseorang hanya dapat diketahui bilamana seseorang itu melakukan interaksi dengan lingkungannya, baik lingkungan pisik-material maupun lingkungan sosial.

${ }^{44}$ M. Arifin, op. cit.., h. 152-154. 
Dalam dunia pendidikan (formal) lingkungan sosialnya adalah para siswa, para guru, dan pegawai sekolah. Sedangkan lingkungan fisik/materialnya adalahsarana prasarana sekolah. Ketika seseorang siswa berinteraksi dengan kedua lingkungan itu segera diketahui bagaimana akhlaknya. Sedangkan metode pendidikan Islam dalam pewarisan nilai-nilai budaya adalah pengarahan, observasi dan belajar dalam pengalaman, penghayatan dan masih banyak lagi metode yang dapat dipergunakan dalam proses pewarisan nilai-nilai dan budaya. 


\section{DAFTAR PUSTAKA}

Almunawar, Said Agil Husin. Aktualisasi Nilai-nilai Qurani Dalam Sistem Pendidikan Islam,Cet; Jakarta: Ciputat Press, 2003.

Arifin, M. Filsafat Pendidikan Islam, Cet.III;Jakarta: Gramedi, 2002.

Arif, Amai. Reformasi Pendidikan Islam, Cet. I; Jakarta: CDRS pres 2008.

Bagus, Lorenz. Kamus Filsafat Cet. III; Jakarta : Gramedia, 2002.

Darajat, Zakiah. Metodik Khusus Pengajaran Agama Islam, Cet. III; Jakarta: Bumi $\quad$ Aksara 2004.

Gazalba, Sidi. Asas kebudayaan Islam Pembahasan Ilmu dan Filsafat tentang Ijtihad, Fiqih, Ahlak, Bidang-bidang Kebudayaan, Masyarakat, Negara, Cet.1; Jakarta: Bulan Bintang 1978.

Getteng Abd. Rahman. Pendidikan Islam dalam Pembangunan Moral, Remaja, Wanita, dalam Pembangunan, Makassar: Yayasan Al-hakam, 1997.

H.A.R.Tilaar, Paradigma baru Pendidikan Nasional, Cet.II; Jakarta: Rineka Cipta, 2004.

Kaheruddin, Pemikiran dan Nilai Etika Pendidikan Islam, Cet.I; Makassar: Yayasan Pendidikan Makassar, 2003.

Langgulung, Hasan. Pendidikan Islam Menghadapi Abad21 Cet.I; JakartaPustaka Al- husna, 1988. Peralihan Paradigma dalam Pendidikan Islam dan Sains Sosial, Cet. 1; Jakarta : Gaya Media Pratama, 2002.

Mudyaharjo, Redja. Pengantar Pendidikan: Sebuah Studi Awal tentang Dasar-dasar Pendidikan pada Umumnya dan Pendidikan di Indonesia Cet. I;Jakarta : Raja Grafindo Persada, 2001.

Muhammad Athiyah al-habsyi, al-Tarbiyah al-Islamiyah, terjemahan Bustami A. Ganidan Djohar Bahry, Dasar-dasar Pokok Pendidikan Islam, Ct.VII; Jakarta: Bulan Bintang 1993.

Mulyana, Rohmat. Mengartikulasikan Pendidikan Nilai, Cet.I; Bandung Al-fabeah, 2004.

Poerbawatja, Soegarda. Enslikopedi Pendidikan, Jakarta: Gunung Agung, 1999.

Qutb, Muhammad. Sistem Pendidikan Islam, Cet. I; Bandung: PT.Al-Maa'rif ,1984.

Redaksi Ensiklopedi Nasional, Ensiklopedi Nasional Indonesia, Jilid III Cet.I ; Jakarta: PT. Cipta Adi pustaka, 1988.

Tafsir, Ahmad. Ilmu Pendidikan Islam Perspektif Islam, Cet. I; Bandung Remaja Rosdakarya, 1992.

Tim Penyusun Kamus Pusat Bahasa, Kamus Besar Bahasa Indonesia, (Cet. III; Jakarta : balai Pustaka, 2005). 